\title{
Estudios Irlandeses
}

Table of Contents Issue 10-2015

\section{ARTICLES}

GERMÁN ASENSIO

Flann O’Brien's Creative Loophole

LEANNE BARTLEY AND ENCARNACIÓN HIDALGO-TENORIO

Constructing Perceptions of Sexual Orientation: A Corpus-based Critical

Discourse Analysis of Transitivity in the Irish Press

MAXIMILIANO BRINA

La voz inconformista de Patrick Kavanagh

ANN WAN-LIH CHANG

A Woman Alone: The Depictions of Spinsters in Irish Women's Short Stories

TONY CROWLEY

Hegemonic Shifts: The Latest from the Walls of Northern Ireland 58

ELISABET DELATTRE

The Great War and All That in A Hundred Doors by Michael Longley.

EVA JERSONSKY

El universo femenino en la prosa temprana de Samuel Beckett:

hacia la autonomía y la mundialización de la literatura

ANTHONY KEATING

Administrative Expedience and the Avoidance of Scandal: Ireland's Industrial and

Reformatory Schools and the Inter-Departmental Committee of 1962-3

\section{INTERVIEW}

SARA MARTÍN-RUÍZ

"The way the Irish asylum system turns people into un-human is my problem":

An Interview with Ifedinma Dimbo 109

\section{THINK PIECE}

AILBHE SMYTH

"Telling the Truth About Women’s Life" March 2015. 


\section{THE YEAR IN REVIEW}

CONSTANZA DEL RÍO (ED.)

Irish Studies in Spain - 2014

PATRICIA A. LYNCH (ED.)

Irish Studies Round the World - 2014...

RUTH BARTON (ED.)

Irish Film and Media Studies Publications - 2014.

RODDY FLYNN, TONY TRACY (EDS.)

Irish Film and Television - 2014 190

ISSN 1699-311X URL: http://www.estudiosirlandeses.org/ 


\section{Estudios \\ Irlandeses}

\section{Electronic Journal of the Spanish Association for Irish Studies (AEDEI)}

